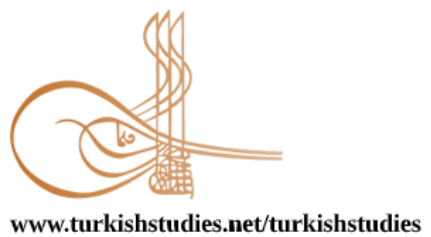

Turkish Studies

\title{
Afetler Çağı, Afetlerin Yapısal Dönüşümü ve COVID-19
}

\author{
The Age of Disasters, Structural Transformation of Disasters and The COVID-19
}

\author{
Celal İnce*
}

\begin{abstract}
Disasters that we encounter, such as the coronavirus disease (COVID-19) situation, constitute an important part of human history. As in history, it causes many people to lose their lives even today, and it is a subject that poses a threat to societies. It does not become outdated, and it focuses on politics, think tanks, and researchers. It is known that there is a transformation in the structure of disasters, which forms a permanent part of the social structure. In this study, the societies' efforts to make sense of disasters, the reasons for the increase of disasters, and the emergence of new types, such as the COVID-19, have been discussed; it theoretically deals with the context of globalization, new technology, social organization, and the complex relationship between forced mass migration and disaster. Also, the questions pertaining to how nature and manmade disasters are intertwined, the meaning change in society, and how globalization, advanced technology, and the new form of social organization increase the destructive power of disasters have been discussed. Besides, the study discusses how forced migration is both a cause and a consequence of disasters and individual and social unequal reflections of the disasters surrounding everyone, and it provides some general recommendations on reducing the number of disasters.
\end{abstract}

Structured Abstract: The primary purpose of this study is to analyse how the disasters occurred in the modern era. The disaster that occurred and social actors need to identify the cause of the structural transformation to develop a policy against disasters and to determine the forms of struggle. This study has been prepared to contribute to such an effort by making use of the literature on disasters and establishing a relationship between disaster and various parameters of social life.

In the modern age, radical changes have occurred in many areas of social life, as well as a transformation in the structure of disasters, which constitute a permanent part of the social structure. When disaster-related studies are examined, it is seen that disasters have started to have a multiple structure. The meaning attributed to the concept of disaster changes in the process. In traditional times and societies, disasters were based on the moral deterioration of human behaviors and were interpreted in terms of religious and cultural doctrines. However, in the modern age, the technical behavior of the human beings is considered to be responsible instead of moral behavior. For example, instead of describing the COVID-19 as a divine punishment, prohibition of eating wild animals in heavenly books, it is often emphasized that the politicians are not getting enough attention, how it came into existence, and what it would result in.

There is a significant increase in the number of disasters, especially human-induced disasters, in the modern age (Furedi, 2007). Disasters caused by nuclear, biological, chemical, and industrial accidents are only

\footnotetext{
* Dr. Öğr. Üyesi Bitlis Eren Üniversitesi, Fen Edebiyat Fakültesi, Sosyoloji Bölümü Asst Prof. Dr. Bitlis Eren University, Faculty of Arts \& Sciences, Department of Sociology

Checked by plagiarism software

Published/Yayın: 30 August/Ağustos 2020

CC BY-NC 4.0
} 
a few of them. Disasters that occur at a local level gain a global dimension due to globalization. Using advanced technology to living an effective social life, on the one hand, provides the opportunity to partially take control of disasters, but it also enables many risks to turn into potential disasters. Modern societies dominated by the instrumental mind and built on the division of labor bring various addictions and new risks. In addition, urbanization and other parameters of the new social organization open new areas of danger. This humaninduced hazard and the increased risk of some of them turning into disasters have more traumatic consequences (Weisæth et al., 2002). It is an important aspect of this traumatic process that other people are considered responsible for mass human deaths. While the increase of disasters leads to the increase in compulsory mass migration, the migration itself may cause a disaster from time to time (Varol \& Gültekin, 2016). Although disasters are phenomena threatening all societies and individuals, the level of economic development of societies and individuals and other forms of capital cause them to be affected in different ways (Bolin, 2007).

One of the other fundamental dynamics related to disasters in the modern era is the emergence of an increasingly complex relationship between disasters and politics. Politics is very useful in turning events into disasters when politics did not take the necessary measures before, during, and after the occasions, or when the measures were taken late and when it does not illustrate successful risk management. This situation may lead to action against the government by the people crowded arrangement of the COVID-19 in the example. Even in this case has the potential to cause even a change of government. On the other hand, in preventing the emergence of political disasters and plays an essential role in controlling. When politics makes a serious preparation against disasters and displays a successful policy against them, it can gain popular favour and strengthen its political positions in democratic societies.

It is possible to find some characteristic features of the change and transformation in the structure of disasters in the modern era in COVID-19. Globalisation, urbanisation, and more interconnected people in modern life have led to the unprecedented rapid spread of the epidemic disease in history. In this context, COVID-19 inherits its destructive power not only from its structure but also from the elements of modern life (Balasubramanian, 2020; Mas-Coma vd., 2020; Nikiforuk, 2018; Beck, 2011). Besides, COVID-19 effects on people who lack various forms of capital, even though it threatens all social strata ${ }^{1}$, as is widely seen in modernday disaster cases.

Especially in the modern age, the increase of human-induced hazards and the fact that a significant part of them result in disasters raises a question like this: Is it possible to take hazards under control and thus prevent disasters altogether? The fact that disasters have formed a part of the social structure throughout the history of mankind is a strong sign that both natural and man-made disasters cannot be eliminated completely (Nikiforuk, 2018). Advanced technology provides an opportunity to control disasters on the one hand, but it causes unstable communities, new risks, and disasters on the other. However, this does not mean that individuals and societies should not prepare for disasters. A decrease in the number of disasters can be seen when the interests of a particular society, or even group of societies, are not sacrificed for the benefit of a certain segment, a particular society, and the state. As in the social contract, it may be possible to limit the disasters and their impact when individuals, communities, and states compromise with comfort to protect their lives from such dangers.

Keywords: Disaster Sociology, Disasters, Coronavirus, Disaster and Inequalities, Disaster and Migration, Disaster and Technology, Disaster and Globalization.

Öz: Yeni Koronavirüs (COVID-19) gibi istisnai bir durum olarak karşımıza çıkan birtakım insan veya doğa kaynaklı olaylar afetle sonuçlanarak insanlık tarihinin önemli bir parçasını oluşturmakta; tarihte olduğu gibi bugün de birçok insanın hayatını kaybetmesine ve toplumsal hayatın alt üst oluşuna neden olmakta; politikanın, düşünce kuruluşlarının ve araştırmacıların odaklandığı güncelliğini yitirmeyen, toplumlar için tehdit oluşturan bir konu oluşturmaktadır. Modern çağda toplumsal hayatın birçok alanında radikal değişimler meydana geldiği gibi toplumsal yapının daimî bir parçasını oluşturan afetlerin yapısında da bir dönüşüm olduğu bilinmektedir. Bu çalışma söz konusu değişim ve dönüşümleri COVID-19 özelinde toplumların afetleri anlamlandırma çabası, afetlerin artış nedenleri ve yeni türlerinin ortaya çıkışı; küreselleşme, yeni teknoloji, toplumsal örgütlenme

\footnotetext{
${ }^{1}$ https://www.brookings.edu/blog/fixgov/2020/04/09/why-are-blacks-dying-at-higher-rates-from-covid-19/, Erişim tarihi: 15.06.2020
}

Turkish Studies, 15(4) 
biçimi, zorunlu kitlesel göç ile afet arasındaki karmaşık ilişki bağlamında teorik olarak konu edinmektedir. Bu kapsamda doğa ve insan kaynaklı afetlerin nasıl iç içe geçtiğini, afetlerin; toplum nezdinde nasıl bir anlam değişikliğine uğradığını, COVID-19 örneğinde olduğu gibi küreselleşme, ileri teknoloji ve yeni toplumsal örgütlenme biçiminin afetlerin tahrip gücünü nasıl artırdığını, afet ile politika arasında nasıl karmaşık bir ilişki biçiminin ortaya çıktığını sorgulamaktadır. Ayrıca çalışma, zorunlu göçün nasıl afetlerin hem nedeni hem sonucu olduğunu ve herkesi kuşatan afetlerin bireysel, toplumsal eşitsiz yansımalarını tartışmakta ve afetlerin sayısının, tahrip gücünün azaltılması ile ilgili sonuç kısmında genel birtakım öneriler sunmaktadır.

Anahtar Kelimeler: Afet Sosyolojisi, Afetler, Koronavirüs, Afet ve Eşitsizlikler, Afet ve Göç, Afet ve Teknoloji, Afet ve Küreselleşme.

\section{Giriş}

Afetler, insanlar için istisnai bir durumdur. Rutin olaylar dışında gelişen ve daha fazla kayıplara neden olan bir süreçtir. Ancak afetlerin karakteristik özelliklerinden biri de tıpk1 'suyun akışına göre hareketini ayarlayan su değirmeni' gibi tekrarlayıcı bir yapıya sahip olmasıdır (Alexander, 2005: 25). Bu bağlamda tarihteki birtakım salgın hastalıklar ve depremler gibi olaylar kitlesel insan ölümlerine yol açarak afetlerin ortaya çıkmasına, toplumsal düzenin alt üst olmasına ve toplumsal davranışların değişmesine neden olmuştur (Nikiforuk, 2018). Orta Çağ'da yayılan salgın (kolera, veba vb.) hastalıklar neticesinde Avrupa'da nüfusun önemli bir kısmı hayatını kaybederken (Gluchman, 2016) bugün de benzer bir biçimde dünyada etkili olan COVID-19 salgın hastalığı nedeniyle dünya genelinde Dünya Sağlık Örgötü verilerine göre 750 binden fazla kişinin hayatını kaybetmesi ve her geçen gün bu sayının artması afetlerin tekrar edici özelliğini göstermektedir. Bu bağlamda insanlık tarihi irili ufaklı afetlerle doludur. Afetlerin bu tekrar edici karakteristik özelliği konunun güncel kalmasına ve araştırılmayı teşvik eden mihenk noktasını oluşturmaktadır. Özellikle günümüz dünyasında afetlerin dünyadaki toplumlar için önemli bir tehdit oluşturması (Lin vd., 2015: 48) yapısal değişime uğrayarak COVID-19 örneğinde olduğu gibi küreselleşmesi, şiddetinin artması, daha tahripkâr olması ve karmaşık bir hal alması farklı disiplinler tarafından bu alana yönelik ilginin dinamik kalmasında belirleyici olmaktadır. Bu çalışma afetlerin bu yeni sayılabilecek karakteristik özelliklerine odaklanmaktadır. Çalı̧̧ma, modern çağdaki afetlerin yapısal değişimini ele alırken, konuyla ilgili mevcut literatürden yararlanarak olgular arasında bir ilişki kurma teşebbüsünde bulunmakta ve betimsel bir analiz gerçekleştirmeye çalışmaktadır.

\section{Afetler Çağı ve Yeni Afet Türleri}

Toplumsal hayatı düşünsel anlamda besleyen birçok edebi, dini, sosyal, kültürel farklı kaynaklarda tarihte farklı toplumların maruz kaldığı afetlerden söz edilmektedir. Bu afetler bazen bir deprem, sel, volkanik patlama bazen de bir çekirge istilası ya da kıtlık olmaktadır. Ancak sözü edilen bu kaynaklarda modern öncesi dönemle ilgili bir nükleer patlamadan ya da biyolojik savaştan söz edilmediği gibi yapılan arkeolojik kazılarda da bu tür bulgulara rastlanılmamaktadır. Dolayısıyla ileri teknoloji ile ilgili kazaların modern döneme özgü olduğu ve modern çağla birlikte bu tür afetlerin ortaya çıktığı anlaşılmaktadır. Modern çağda hem yeni afet türleri ortaya çıktı hem de daha önceki doğa kaynaklı afetlerin tahrip gücü arttı. Özellikle dünyanın belli coğrafyalarındaki afetlerin sayısında ve yoğunluğunda bir artı̧̧ oldu (Perrow, 2007). Bu kapsamda insanoğlunun doğayı dönüştürme operasyonu hız kazanırken yeni tehlike ve riskler ortaya çıkmaya devam etmektedir. Başka bir ifade ile afetlerin sayı ve yoğunluk açısından artışı insanın doğaya müdahalesi neticesinde olmaktadır (Nikiforuk, 2018). Depremler sonucunda nükleer santrallerde kaza meydana gelebilmekte, füze denemeleri sonucunda tsunami etkisi ortaya çıkabilmektedir (Özer, 2017: 1). Dünya, doğa ve insan kaynaklı olmak üzere her yıl yaklaşı 300 afete şahitlik etmekte ve gün geçtikçe bu sayı daha da artma eğilimi göstermektedir (Alexander, 2005: 25). Afetler kadim bir olgu olmakla birlikte modern dönemde yeni formlar kazanmakta, yeni türleri ortaya çıkmaktadır

\footnotetext{
${ }^{2}$ https://www.who.int/emergencies/diseases/novel-coronavirus-2019, Erişim tarihi: 15.08.2020
} 
(Qurantelli vd., 2007: 16). Hatta ortaya çıkan bu yeni durumun sadece insan hayatını değil bitki ve hayvanlara yönelik geri döndürülemez tehlikeler de içerdiği ileri sürülmektedir (Beck, 2011: 14).

Bu bağlamda modern çağ; genellikle küresel çatışmaların arttığı ve bu çatışmalarda tahrip gücü yüksek yeni ileri teknolojik araçların kullanıldığı, soykırımların ve 'etnik temizlik' operasyonlarının yapıldığı, endüstriyel ve tarımsal değişimlerin meydana geldiği, çevresel afetlerin olduğu, kitlesel ölümlerin gerçekleştiği afetler çağ 1 olarak değerlendirilmektedir (Furedi, 2007). Böyle devam ederse her geçen gün toplumların daha fazla kitlesel ölümcül olaylara şahit olacağı ve afetlere daha fazla insanın maruz kalarak hayatını kaybedeceği tahmin edilmektedir (OECD, 2003: 5). $\mathrm{Bu}$ artışa paralel olarak afet kavramına yüklenilen anlam da değişmektedir. Afet; artık 'alışılmadık, benzersiz, beklenmedik' bir gelişme yerine giderek gündelik hayatın bir parçası haline gelmektedir (Furedi, 2007). Diğer taraftan afetlerin yeni özellikler kazanması ve olayların tahrip gücünün artması, afetlerin dünya düzenini her an alt üst edebilecek ve politikayı dönüştürebilecek potansiyele de sahip olmaya başladığı görülmektedir. Bu bağlamda modern çağda afetlerle ilgili değişen temel diğer dinamiklerden biri de afetler ile siyaset arasında giderek karmaşık bir ilişkinin ortaya çıkmasıdır. Olaylardan önce, olaylar sırasında ve olaylar sonrasında siyaset gerekli tedbirleri almadığında ya da tedbirleri geç aldığında olayların afete dönüşmesine neden olmaktadır. Bu kapsamda halk, afet yönetimi konusunda devlet yöneticileri üzerinde bir baskı kurabildiği gibi iktidarda bulunan yöneticiler de zaman zaman afetleri konumlarını tahkim etme açısından bir firsata dönüştürebilmektedir.

Balasubramanian (2020) çalışmasında belirttiği üzere "küresel 1sınma, hızlı sanayileşme, ormansızlaşma, doğal yaşam alanlarının kaybı" ve modern hayatın sunduğu stresli yaşam COVID-19 gibi yeni tehlikelere kapı aralamaktadır. OECD'nin (2003: 5) hazırlamış olduğu çalışmada görüldüğü gibi dünya 21. yy'da afet ve risk bağlamında yeni sayılabilecek bir sürece girmektedir. Dünya genelinde büyük çaplı afetlerin meydana gelmesi bu yeni dönemin şifrelerini oluşturmaktadır. Küreselleşme ve iklim değişikliği yeni bulaşıcı hastalıkların ortaya çıkmasına ve yayılımına firsat sunmaktadır (Mas-Coma vd., 2020). Afetlertin Yapısal Dönüşümü ve COVID-19 adlı başıık altında daha detaylı ele aldığımız COVID-19 salgın hastalığı gibi yeni küreselleşen salgın hastalıklar, terör saldırıları, sarin gazı saldırıları, savaşlardaki kitlesel ölümler, sellerin, depremlerin ve firtınaların yıkıcılı̆̆ının artması, alt yapıların ve sistemlerin bir anda çökmesi, teknik arızaların meydana gelmesi 21. yy. afetlerinin alametifarikalarını oluşturmaktadır. Modern çağda sadece afetlerin yapısı değişmemekte aynı zamanda içinde bulundukları bağlam ve toplumun bunları yönetme kapasitesi de dönüşmektedir. Zaman ve mekâna içkin olan afet, farklı kategorilerle eklemlenerek çok boyutlu bir hal almaktadır (Teodorescu, 2015).

Diğer taraftan şiddete dayalı hegemonyasını devam ettirmek isteyen küresel aktörler; savaş, iç çatışma, zorunlu kitlesel göç ve terörist saldırılara neden olarak afet etkisi ortaya çıkartabilmektedirler. Yakın zamanda sayısında artış görülen bu tür hareketlenmeler, Giddens'a (2012: 87) göre doğal kaynaklı afetlerle kıyaslandığında daha sorunlu alanlar oluşturmaktadır. 21. yy'da yüz milyondan fazla insanın diğer insanlar tarafından kasıtlı olarak öldürülmesi ve giderek bu sayının artış yönünde bir eğilim sergilemesi tehlikenin boyutuna işaret etmektedir (Fink, 2010). Söz konusu hareketlenmeler aynı zamanda savaşların yapısında da bir değişim olduğunu göstermektedir. Afet açısından bu değişimin en çarpıcı özellikleri arasında savaşların ticarileşmesi ile birlikte ekonomik bir faaliyete dönüşmesi, şiddetin artmasıyla ters orantılı olarak daha ucuz olması, geniş bir nüfusu etkisi altına alması, ne zaman biteceği belli olmaması sivil halkın hedef haricinde tutulmaması ve tahrip gücünün oldukça fazla olması gibi unsurlar gelmektedir (Münkler, 2010). Savaşlarda olduğu gibi terör saldırılarının yapısında da bir dönüşüm meydana gelmektedir. Yeni terörist saldılarda; ileri teknolojinin kullanılması, askeri ve siyasi liderlerin yanında sivil halkın da sürece dahil edilerek bekleme noktaları, toplanma merkezleri gibi kalabalık mekânların hedef haline gelmesi, insanın sosyal ve psikolojik durumu üzerinde oluşturduğu etkiler hem afet potansiyelini artırmakta hem de tehlikenin doğasını temelden değiştirmektedir (Waugh, 2007). 
Günümüz toplumlarında bir yandan doğa kaynaklı deprem, çekirge istilası, seller, salgın hastalıklar gibi eski tip afetler devam ederken diğer yandan da bu afetler yeni boyutlar kazanarak temel yapılarında önemli değişimler meydana gelmektedir. Aynı zamanda bu afet türlerine biyolojik savaş, teknik arızalar, alt yapının çökmesi, ozon tabakasının delinmesi, terörist saldırılar gibi insan kaynaklı ve doğa-insan eklektiği neticesinde ortaya çıkan hibrit afet tipi sayılabilecek yeni afet türleri dâhil olmaktadır. Toplumlar modernleştikçe, endüstrileştikçe, kentleşme arttıkça, teknoloji ilerledikçe ve belki de en önemlisi derinlikli bir önlem alınmadıkça, toplumsal fayda belli bir kesimin çıkarına feda edildikçe tehlikelerin temel doğası değişmektedir. Yeni tehlikelere karşı başarılı bir risk yönetimi ortaya çıkmadığında toplumların daha fazla kitlesel ölümlere şahit olarak yeni afetlerle karşı karşıya kalacağı anlaşılmaktadır (Perry, 2007).

\section{Afetlerin Yapısal Dönüșümü}

Modern çağla birlikte toplumsal hayatın birçok alanındaki hızlı değişim afetlerin yapısında da bir dönüşüme neden olmaktadır. Eski afetlere yeni afetler eklenmekte ve afetler toplumsal yapıların her alanında ortaya çıkan değişimlerle eklemlenerek yeni formlar kazanmaktadır. Ancak bir makalede bütün bu değişimleri detaylı bir biçimde analiz etmek mümkün olmadığından bu çalışmada sınırlı bir biçimde daha çok belli başlıklar altında konu değerlendirilmeye çalışılmaktadır.

\subsection{Afetleri Anlamlandırma Çabasındaki Değişim}

Geleneksel dönem modern döneme evrilirken afetleri anlamlandırma çabasında da bir değişim olmuştur. Birçok semavi kaynakta insanların ilahi fermanlara uygun hareket etmediği zamanlarda ve ahlaki bozulmanın zirveye ulaştığı dönemlerde yaratıcı tarafından çeşitli olaylarla (sel, volkanik patlama, kıtlık vb.) cezalandırıldığı belirtilmektedir (Okumuş, 2002). Bu kapsamda geleneksel dönemde semavi dinlerin müntesipleri, hatta diğer dinlere intisap eden insanlar, toplumsal hayatı tahrip eden ve kitlesel ölümlerin gerçekleşmesine neden olan olayların aşkın bir gücün eylemi neticesinde ortaya çıktığına inanırlardı ve bu tür olaylar aşkın gücün doğru yoldan sapan insanlara yönelik öfkenin bir tezahürü olarak yorumlanırdı.

Pozitivist paradigmanın yükselişe geçtiği, ampirik verinin bilginin esas kaynağ öngörüldüğü ve dünyaya yüklenilen anlamın farklılaştığı modern dönemle birlikte insan-doğa ilişkisini anlamlandırma tasavvurunda radikal bir değişim olduğu gibi afet etkisi ortaya çıkaran olayların doğasını ve kaynağını anlamlandırmada ve düşünce sisteminde bir dönüşüm oldu. Modern toplumlarda artık neredeyse bütün olayların faili aşkın güç değil insan eylemleri olduğu yönünde bir anlayış ortaya çıktı. Bu bağlamda afetlere sebep olan doğa kaynaklı olayların mistik anlamını yitirdiğine ve bu olayların insanlar tarafından kontrol altına alınabileceğine dair inanç modern dönemle birlikte giderek güçlenmeye başladı. Meydana gelen afetlerin esas sorumlusu, yıkımın müsebbibi olarak çoğu zaman ya kamu görevlileri ya büyük organizatörler ya da plansız yapılaşmalar görülmeye başlandı. Modern toplumlarda doğa kaynaklı birçok afetin bile insan eylemlerinin neticesinde ortaya çıktığı görüşü ağır bastı (Furedi, 2007). Tarihsel olarak bu değişen düşüncenin numunelerini COVID-19'da bulmak mümkündür. COVID-19'un ortaya çıkışı ve yayılışı biraz daha geleneksel toplumlarda ilahi bir ceza olduğuna inananlar olmakla birlikte özellikle modern toplumlarda sağlı sistemine ve politik kararlara dayandırıldı. COVID-19'un ortaya çıkışı açısından semavi dinlerdeki vahşi hayvanların yenilmesinin yasaklanması ile COVID-19'un vahşi hayvanlardan insana geçip geçmediği tartışması yerine COVID-19'un muhtemel sonuçları üzerinde durulmaktadır. COVID-19'un ilahi bir ceza olduğu tartışması yerine çoğu zaman politikacıların yeterli düzeyde önlem almaması, nasıl ortaya çıktığı, biyolojik bir savaş olup olmadığı, laboratuvar ortamında üretilip üretilmediği ve ne tür sonuçlara neden olacağı tartışılmaktadır. Örneğin, COVID19'a ilk süreçte ev sahipliği yapan Çin'de, uzmanlar tarafından salgın hastalığın yapısı ile ilgili bilgilendirmeler yapılmasına ve küreselleşme olgusuyla dünyaya yayılımı muhtemel görülmesine rağmen politikacıların gerekli önlemleri almaması sorgulanmaya tabi tutulmaktadır (Mas-Coma vd., 2020). 
Afet ile ilgili modern çağda meydana gelen bu alg1 değişikliği genelde dünyayı anlamlandırma çabasında ortaya çıkan bütünsel bir tasavvurun göstergesidir. Başka bir ifade ile modernleşme, "karşıtının, yani, dinin geleneksel dünyası anlaşılıp hükmedilmesi gereken doğanın zeminlerinde ortaya" çıtı (Beck, 2011: 9) ve varlığı anlamlandırma çabasını bir yönüyle dinin karşıtlı̆̆ 1 üzerine inşa etti. Bazı teorisyenler tarafından bilimin ilerlemesi ile birlikte dünyanın büyüsünün bozulduğu, toplumların daha düzenli hale geleceği ve daha kontrollü sosyal sistemlere dönüşeceği varsayıldı (Turner, 2002: 252). Bu kapsamda özellikle doğa kaynaklı afetlerin insanların kötü gidişine dur demek ve insanları terbiye etmek için bir yaratıcı tarafından halk edildiği düşüncesini ileri süren dini aktörlerin söylemleri sert bir şekilde eleştirildi. ${ }^{3}$ Ancak olayları dini doktrinlerle açıklama ve anlamlandırma çabası pratik düzeyde farklı bağlamlarda ve modernite trenine geç binen toplumlarda etkisini devam ettirdi. Modern toplumlarda da post-modernite, geç modernite ve sanayi sonrası toplum gibi yeni kavramla ifade edilen yeni süreçle birlikte toplumların daha kontrollü hale geleceği düşüncesi terk edilerek tam tersi risklerin, belirsizliklerin, tehlikelerin yeni toplumsal örgütlemenin karakteristik özelliği haline gelmeye başladığı düşünülmekte ve toplumsal kontrolün sağlanacağına dair inanç giderek zayıflamaktadır (Beck, 2011).

\subsection{Afetlerin Küreselleşmesi}

Günümüz afetlerinin değişen diğer karakteristik bir özelliği küreselleşme olgusuyla eklemlenerek yeni boyutlar kazanmasıdır. Küreselleşme, insanlara birtakım imkânlar sunsa da aynı zamanda afet açısından birçok risk de barındırmaktadır. Küreselleşmenin ekonomik, teknolojik, kültürel ve çevresel boyutları genişlerken, coğrafyaların, ülkelerin, toplumların birbirine bağımlılığ artmakta, bu süreçle birlikte kirliliğin, teknik arızaların ve salgın hastalıkların yayılımı kolaylaşarak yeni tehlikelere kapı aralanmaktadır (OECD, 2003). Çin'in Wuhan kentinde ortaya çıkıp neredeyse bütün dünyaya yayılan COVID-19 gibi yerel tehlikeler yerel olma özelliğini yitirerek küresel bir fenomene dönüşmektedir. Geleneksel dönemlerde ya da modernleşmenin ilk aşamasında yerel ve mesleki tehlikeler mahdut bir mekânda afetlere dönüşürken ve afetin etkileri belli bir coğrafya ile sınırlı kalırken yeni salgın hastalıklar, nükleer patlamalar, çevre kirliliği ve biyolojik savaşlar gibi tehlikeler küreselleşme eğilimi göstermektedir. Yerel afetler yerelle sınırlı kalmamakta küresel bir sorun haline gelmektedir. Modernleşmenin afet riski taşıyan sonuçları yerel ve ulusal sınırları aşarak "yeni bir sosyal ve siyasi dinamizme sahip küresel tehlikeler" içermektedir (Beck, 2011: 14).

Küreselleşme ile birlikte iki ülke arasında gerçekleşen ya da bir ülkedeki iç savaşın etkileri sadece bu ülkelerle sınırlı kalmamakta savaşla ilgisi olmayan toplumları, devletleri bile doğrudan veya dolaylı bir biçimde kitlesel göç, ekonomi gibi olgular üzerinden etkilemektedir. Bu bağlamda küreselleşme afetlerin şiddetini artırarak uluslararası ilişkilerin ana temalarından birini oluşturmaktadır (Alexander, 2005: 34). COVID-19 salgın hastalığı bu duruma en iyi örneklerden birisidir. Geleneksel dönemlerde de zaman zaman ortaya çıkan salgın hastalıklar sadece belli bir coğrafyada etkili olurken uluslararası insan hareketliliğinin oldukça fazla olduğu günümüzde ortaya çıkan COVID-19 salgın hastalığının dünyaya yayılımı haftalar içerisinde gerçekleşmiştir. Yakın zamanda salgın hastalıkların yayılımında aktif rol alan küreselleşmenin (Mas-Coma, 2020) gelecekte de benzer bir misyon üstleneceği düşünülmektedir.

Küreselleşme, bir taraftan afet etkisini artırırken diğer taraftan Giddens'a (2012: 87) göre ulusları aşan bir toplumsal sorumluluğu da beraberinde getirmektedir. Dünyanın bir diğer tarafında insanların karşı karşıya kaldığı bir deprem, sel baskını ya da kıtlık uluslararası toplumun müdahale etmesi gereken meşru alanlar oluşturmaktadır. Bu bağlamda doğa veya insan kaynaklı çeşitli olaylara maruz kalan afetzedelerin durumlarını iyileştirmek için uluslararası toplum tarafından eyleme geçme yükümlülüğü olduğu giderek daha fazla kabul gören bir varsayım haline gelmektedir. Can ve mal kaybının oldukça fazla olduğu bir deprem sonrasında hem arama kurtarma hem de durumun

\footnotetext{
${ }^{3}$ Türkiye'de bu tasavvurun nüvelerine sıç̧a rastlamak mümkündür. Afet zamanlarında bunun ilahi bir ceza olduğunu ileri süren söylemler sert bir biçimde eleştirilmekte ve çeşitli protestolara sahne olmaktadır.
} 
iyileşmesi sürecinde uluslararası toplumun sürece dâhil olma talebi bunun örneğini oluşturmaktadır. COVID-19 sonrasında bazı ülkeler arasındaki yardımlaşma ve dayanışma faaliyetlerini de bu kapsamda değerlendirmenin uygun olabileceği düşünülmektedir. Başka bir ifade ile sorunlar küreselleştikçe küresel çözümler de daha fazla ihtiyaç haline gelmektedir (Balasubramanian, 2020).

\subsection{Teknoloji ve Afet}

Teknoloji ile afet arasında karşılıklı bir ilişki söz konusudur. İkili bir karaktere sahip olan teknoloji, afetlere neden olabildiği gibi afetlerin ortaya çıkışını engellemede ve kontrol altına alınmasında da bir imkân sağlamaktadır (Weisæth vd., 2002: 34). Bu bağlamda ileri teknolojinin toplumsal hayatın birçok alanında kullanıma girmesi bir taraftan toplumsal refahın artışına katkı sunarken diğer taraftan afetlerin esas kaynağı haline gelmeye başlamaktadır (Gluchman, 2016). Toplumsal hayatın birçok faklı sahasında başvurulan ileri teknoloji afetle sonuçlanarak yeni kitlesel ölümlere yol açmaktadır. Beck, bu süreci 'risk toplumu' kavramıyla açıklamaktadır (Beck, 2011: 14). İleri teknoloji daha çalkantılı ve istikrarsız toplumlar tarihinin oluşumuna katkı sunmaktadır (Nikiforuk, 2018: 12).

$\mathrm{Bu}$ bağlamda geleneksel dönemde daha çok doğa kaynaklı afetler meydana gelirken günümüzde teknik-ekonomik ilerleme risk üretiminin ana kaynağı haline dönüşmektedir. Birçok sosyal ve siyasi tartışmaların merkezi konumunu oluşturan risk üretimi yeni afet türlerinin, doğa ve insan kaynaklı afetlerin iç içe geçerek hibrit afetlerin ortaya çıkışına kapı aralamaktadır. Bu bağlamda araçsal akıl ve araçsal aklın kutsallaştırdığı ileri teknolojinin toplumsal yaşamı ele geçirmesi yeni tehlikeleri ve afetleri beraberinde getirmesi açısından yüksek risk taşımaktadır. Araçsal akıl açısından faydayı maksimize etme çabası, merkezi yer tutarken bu anlayış biçimi sadece belirli bir kesimin ihtiyaçlarını göz ardı etmemekte doğanın ihtiyaçlarına karşı da duyarsızlaşmakta ve 'insan hayatına dolar cinsinden bakmaktadır' (Taylor, 2011: 13). Araçsal aklın egemen olduğu ve işbölümü esası üzerine inşa edilen modern toplumlar çeşitli bağımlılıkları ve yeni riskleri beraberinde getirmektedir.

Toplumlar modernleştikçe ve ileri teknolojiye sahip oldukça eski tehlikelere yeni tehlikeler eklenmekte ve toplumsal yaşamı tehdit eden yeni riskler ortaya çıkmaktadır. Doğal tehlikelere kimyasal, nükleer ve biyolojik riskler de dahil olmaktadır (Quarantelli vd., 2007: 17). Bununla birlikte modern dönemde aşırı üretim ve tüketim faaliyetleri de toplumsal hayatı etkisi altına alarak yeni tehditlerin ortaya çıkmasına zemin hazırlamaktadır. İleri teknolojinin sağladığı imkân ile modernleşme sürecinde üretici güçlerin kartopu gibi katlanarak büyümesi daha önce görülmemiş bir biçimde ve ölçekte yeni tehdit ve tehlikelerin ortaya çıkmasına olanak sunmaktadır (Beck, 2011: 21). $\mathrm{Bu}$ kapsamda pozitivist paradigma modern çağın ilk sürecinde doğa üzerinde hakimiyetini ve kontrolünü sağladığını ilan ederken tarihte hiç olmadığı kadar bu dönemde hava, su, toprak ve çevre kirliliğinin meydana gelmesi asit yağmurlarının yağdırılması gibi yeni afet türlerine yol açmaktadır. İnsan kaynaklı afetlerin artışı, insan ihmali ve insanın suçlanılabilmesi nedeniyle doğal afetlere göre daha travmatik sonuçlar doğurmaktadır (Weisæth vd., 2002: 35). Bu kapsamda Beck’e (2011: 22) göre doğayı kontrol altına alma çabası tekno-ekonomik gelişimin kendisinden doğan sorunları kontrol altına alma çabasıyla iç içe geçerek modernleşme süreci, kendi kendisini konu ve sorun edinen dönüşlü (reflexiv) bir hale gelmektedir. Nitekim COVID-19'un laboratuvar ortamında üretilmiş olabileceği ya da biyolojik bir savaş olduğuna dair birtakım değerlendirmeler gerçek olmasa bile teknolojinin sunmuş olduğu imkân ile böyle bir uygulamanın mümkün olabileceğini göstermektedir.

Şüphesiz ileri teknolojinin kullanımı ile birlikte tehlikenin bulaştığı alanlardan biri de gıda ürünleridir. İleri teknolojin sağladığı imkân sayesinde gida maddelerinin hem uzun süre saklanabilmesi hem de ulusal sınırları aşarak, dünyanın her tarafına taşınabilmesi olanaklı hale gelerek sağlık açısından yeni tehlike ve risk alanları açmaktadır (Giddens, 2012: 298). Her gıdaya 
her mevsim ulaşılabilmenin olası hale gelmesi beslenme bozukluklarının ortaya çıkmasına neden olduğu gibi verimi artırmak için gıdanın üretim sürecinde aşırı ilaç kullanımı bağışıklık sisteminin zayıflamasını da beraberinde getirmektedir. Bu durum özellikle bağışıklık sisteminin önemli hale geldiği salgın hastalıklarda daha fazla insanın ölmesine yol açabilmektedir.

\subsection{Yeni Toplumsal Örgütlenme Biçimi Açısından Afetler}

Yeni dönemle birlikte sadece afetlerin doğası değişmemekte, afetlerin içinde meydana geldiği toplumun örgütlenme biçimi de değişmekte ve bu yeni örgütlenme biçimi olayların tahrip gücünü artırarak daha büyük çaplı afetlerin ortaya çıkmasında rol oynamaktadır. Şüphesiz modern hayatın örgütlenme biçiminin önemli bir parametresini kentleşme oluşturmaktadır. Günümüzde dünyanın birçok ülkesinde, özellikle modern toplumlarda nüfusun büyük çoğunluğunun artık kentlerde ikamet etmesi yeni tehlikeleri beraberinde getirmekte, bireyleri ve toplulukları risklere karşı daha açık hale getirmektedir. Kent merkezlerinde nüfus homojen dağılmamakta kentin belirli bölgelerine yönelmektedir. Sadece nüfus değil sanayi ve üretim faaliyetleri de belirli mekânlarda yoğunlaşmaktadır. Bu yoğunlaşma söz konusu mekânları kitlesel olaylara karşı daha savunmasız bir hale getirerek afetlerin ortaya çıkma riskini artırmaktadır (OECD, 2003: 5). Bu bağlamda yeni toplumsal örgütleme biçiminin mayasını oluşturan endüstrileşme, kentleşme, küreselleşme ve ileri teknoloji, risk toplumunun ana kaynağını oluştururken afetlerin yapısında bir değişime neden olmaktadır. Afetlerin bu yapısal dönüşümü afetleri çözümlemek üzere geliştirilen kavramların, ilkelerin ve ilgili terminolojinin kifayetsiz kalmasına ve dolayısıyla yeni bir kavramsal çözümleme ihtiyacını ortaya çıkarmaktadır (Perry \& Quarantelli, 2005).

Olayların tahrip gücünü artırması açısından ketlerdeki fiziksel ve sosyal temasın kolay olması özellikle salgın hastalıklar açsından büyük bir risk taşımaktadır. COVID-19 örneğinde olduğu gibi sosyal temasın ve bağımlılığın oldukça fazla olduğu kent merkezlerinde salgın hastalıkların yayılımı çok daha hızlı gerçekleşmektedir. Diğer taraftan kentlerin çöküntü mekânları deprem gibi fiziksel olaylara karşı daha savunmasız hale gelmektedir. Düzensiz ve plansız kentleşmenin olduğu yapılarda tehlikenin afete dönüşme ihtimali artmakta ve deprem gibi olaylarda daha fazla can kaybının gerçekleşmesinde etkili olmaktadır (Weisæth vd., 2002: 35).

Modern hayatın toplumsal örgütleme biçiminin diğer önemli bir veçhesini uzmanlaşmaya dayalı işbölümü oluşturmaktadır. Modern hayata özgü olan işbölümü, Emile Durkheim (2006) açısından toplumsal bütünleşmeyi sağlayan önemli bir kaynak olsa da afetler açısından toplumun daha kırılgan bir yapıya sahip olmasına yol açmaktadır. İş bölümü üzerinden gittikçe birbirine bağımlı halen toplumsal hayatın farklı kategorileri kitlesel olaylara karşı daha savunmasız hale gelmektedir. Günümüzde belirli bir alanda ya da sınırlı bir mekânda ortaya çıkan bir olay kartopu gibi büyüyerek sağlık hizmetlerini, ulaşımı, enerjiyi, gıdayı ve su kaynaklarını, bilgi ve telekomünikasyonu olumsuz etkileyebilecek potansiyele sahip olarak kitlesel afetlerin ortaya çıkmasında belirleyici olmaktadır (OECD, 2003: 5).

\subsection{Afetler ve Eşitsizlikler}

Modern çağda insanların ve toplumların sahip oldukları konumlarına bağlı olarak olaylardan etkilenme durumları da oldukça farklı olmaktadır. Genel olarak afetlerden kaynaklanan ölüm ve yaralanmaların sayısı bir ülkenin ekonomik kalkınma düzeyiyle yakından ilişkili olmaktadır (Weisæth vd., 2002: 34). Diğer taraftan afetler toplumun bütün bireylerini kapsamakla birlikte "toplumsal kümeler ve sınıflar afeti birbirlerinden farklı koşullarda" deneyimlemektedir (Akgüngör, 2010: 5). Toplumlar ve insanların dönemin koşullarına bağlı olarak sahip olduğu imkânlar, yaşadığı coğrafya, deneyim ve bilgi, onların bu süreçten ne düzeyde etkilenebilecekleri konusunda belirleyici olmuştur. Tehlikelerin fazla olduğu mekânlarda yaşayan, bilgi ve beceri konusunda zayıf olan ve maddi imkânlardan yoksun olan birey ve topluluklar afetlere karşı daha savunmasız bir görünüm sergilemektedir. Bireyler ve toplumlar arasındaki bu olaylardan etkilenme düzeyi farkı algılananın aksine günümüz toplumlarında giderek daha derinleşmekte ve çatallaşmaktadır. Bu bağlamda afetle 
ilgili yapılan araştırmaların bulguları toplumsal eşitsizliklerin afetleri nasıl şekillendirdiğini açıkça göstermektedir (Bolin, 2007: 113).

Ekonomik alanda egemen politika haline gelen kapitalist ve özelde neo-liberal politikaların uygulanması ile birlikte dünya üzerinde bölgeler arasındaki refah düzeyi farkı giderek derinleşti. Bu farkın göstergelerine toplumsal hayatın birçok alanında rastlansa da en bariz yansımalardan biri toplumların afetlere maruz kalma safhasında rastlanılmaktadır. Günümüz toplumlarda başta sağlık hizmetleri olmak üzere refah düzeyinin düşük olduğu toplumlarda afet etkisi daha şiddetli olmaktadır. Örneğin sağlık hizmetlerinin yok denecek kadar düşük olduğu bazı ülkelerde bebekler ve çocuklar aşı olamadığı için her yıl binlerce çocuk hayatını kaybederken refah düzeyi yüksek ülkelerde bu sayı yok denecek kadar az olması çarpıcı bir örnek oluşturmaktadır. Bu ilişki biçimini COVID-19 sürecinde de gözlemlemek mümkündür. COVID-19 ile mücadelede aş1 çalışmaları zaman alacağından temel önceleyici parameterelerden biri hastalığın yayılımını engellemektir. Uzun süre bütün kesimleri kotrol altında tutmak toplumsal hayatın davamını sağlamak açısından zor olduğundan COVID-19'a yakalanmış kişilerin tanı testi uygulaması genişletilerek tespit edilip gözetim altına tutulması daha uygulanabilir bir yöntem görünmektedir ve Dünya Sağlık Örgütünün tavsiyeleri de bu yöndedir. Ancak yoksul ülkeler bu imkâna sahip olmadığından hastalığın yayılımı daha kolay olmaktadır (Mas-Coma vd., 2020: 1). Diğer taraftan aşı çalışmaları başarılı bir biçimde sonuçlansa bile yoksul ülkelerde hizmete sunulması uzun zaman alacağı düşünülmektedir.

Sadece farklı ülkeler arasında değil refah düzeyi yüksek neo-liberal politikaların baskın bir biçimde uygulandığı ülkelerde bile bireyler arasındaki derin sosyo-ekonomik farklılık, etnik ve sınıfsal eşitsizlik, insanların olaylardan farklı şekilde etkilenmesine neden olmaktadır. Bolin'in (2007) çalışması toplumsal sınıf ile afet arasındaki ilişkiyi vurgulamak açısından önemli bir bakış açısı sunmaktadır. Bu çalışmaya göre ABD'de sık sık meydana gelen ve afetle sonuçlanan Katrina kasırgasına karşı on binlerce Afrika kökenli düşük gelirli Amerikalıların daha savunmasız olması, etnik ve sınıf eşitsizliklerin gelişmiş toplumlarda ne kadar güçlü olduğunu göstermektedir. Yine COVID-19 salgın hastalığı sürecinde Batı Avrupa, ABD gibi ülkelerde hastalığa yakalanan sosyoekonomik düzeyi yüksek bireyler hastane hizmetlerinden maksimum düzeyde yararlanmaktadır. Fakat bazı huzur evlerinde hastalığa yakalanan yaşlı yoksul bireylerin hastaneye bile gidememesi, huzur evlerinde toplu ölümlerin gerçekleşmesi ${ }^{4}$ afet ile toplumsal konum arasındaki çapraz ilişkiyi vurgulayan bir gösterge olmaktadır. Diğer taraftan COVID-19'a bağlı ölümlerin önemli bir kısmı 60 yaş üstünü oluşturan kişilerden oluşmasına rağmen özellikle gelişmiş ülkelerde kategorik olarak yaşl1lara yönelik sağlık ve kontrol hzimetlerinde bir öncelik tanınmaması, sosyal savunmasız bir grup olarak yaşılıların afetlere karşı savunasızlıklarını derinleştirmektedir (Mas-Coma, 2020).

Dünyanın birçok bölgesi farklı afet türlerine maruz kalırken sanayiye bağlı ortaya çıkan afetler belirli bölgelerde yoğunlaşmaktadır. Beck'e (2011: 58) göre; gelişmiş ülkelerin 3. dünya ülkelerine transfer ettiği ağır ve riskli sanayi, sınıf konumları ile risk konumlarının nasıl örtüştüğünü ve afetlere neden olan risklerin eşitsizlikler özelinde uluslararası ölçekte nasıl dağıldığını apaçık göstermektedir. 1984 yılında Hindistan'daki ABD kökenli böcek ilacı fabrikasında meydana kaza sonucu 18 bin kişinin ölmesi, yaklaşık 200 bin kişinin zehirlenmesi, olumsuz etkilerinin uzun yıllar devam etmesi ve buna benzer birçok endüstri kazanın daha meydana gelmesi yoksulluk ile risk ve dolayısıyla sınıfsal konum ile afet arasındaki sistematik ilişkiyi gösteren bariz bir örnek oluşturmaktadır.

\subsection{Afet ve Zorunlu Kitlesel Göç}

Afet ve göç arasında iki yönlü ilişkisi söz konusudur. Bunlardan birisi afete neden olan doğa veya insan kaynaklı olaylar sonucunda COVID-19 örneğinde olduğu gibi insanların göç etmesi ya da göç ettirilmesi diğeri ise özellikle zorunlu kitlesel göçler sonucunda afet etkisinin ortaya çıması

\footnotetext{
${ }^{4}$ http://m.haber7.com/guncel/haber/2975792-kayiplarin-yuzde-yetmisi-huzurevinde, Erişim tarihi: 18.05.2020
} 
ya da çıkma ihtimalidir (Tunç, 2018). Ancak doğal kaynaklı afetlerde olduğu kadar savaş, terörist saldırlar ve kitlesel zorunlu göçler gibi sosyal olaylar ile afet arasındaki ilişki analiz edildiğini söylemek mümkün değildir (Boin \& 'T Hart, 2007) Tunç'a göre "doğal, teknolojik ve/veya insan kaynaklı afetler kitlesel göçe neden olabilmekte, kitlesel göç ise devletler ve toplumlar üzerinde ekonomik, demografik, sosyal ve kültürel boyutta afet etkisi yaratabilmektedir" (Tunç, 2018: 69). Nitekim afetle bağlantılı olarak kullanılan acil durum, kriz, mülteci krizi, insani kriz, risk gibi kavramlar kitlesel göç hareketlerinde sıklıkla başvurulan kavramlar olmaktadır.

İnce'ye göre "tarihsel olarak insan yaşamını tehdit eden koşullar belirginleştiğinde ve savunmanın mümkün olmadığı düşünüldüğünde mücadelenin bir biçimi olarak insanların riskler barındıran mekânları terk etmesi başvurulan ana stratejilerden biri olmuştur" (İnce, 2019: 208). Bu bağlamda tehlikeden uzaklaşmak ve riskleri azaltmak adına göç insanlar tarafindan başvurulan tarihsel bir taktik olduğu görülmektedir. İnsanlık tarihi incelendiğinde insanların sürekli yer değiştirdiği bilinmektedir. Ancak günümüz dünyasında savaş, terör saldırıları, ekolojik dengenin bozulması, çevrenin kirletilmesi gibi afetlere bağlı olarak ortaya çıkan tehlikeden uzaklaşmak isteyenlerin sayısında baş döndürücü bir biçimde gerçekleşen artış, modern çağdaki afetlerin karakteristik bir özelliğine dönüşmektedir. Bu kapsamda sadece 2016 yılında savaş, çatışma ve doğa kaynaklı afet nedeniyle 27.8 milyon insan yerinden edilirken 2016 y1lına kadar bu sebeplerden dolay1 toplam 203.4 milyon insanın yerinden edildiği rapor edilmektedir (Tunç, 2018: 75'te belirttiği gibi).

Günümüz dünyasında göçün artışında rol oynayan dinamiklerin başında küreselleşme, kapitalizm, bölgelerarası refah farkı, emeğe dayalı arz-talep ilişkisi, ulaşım ve iletişim alanında meydana gelen gelişmeler gelmektedir. Zorunlu göçlere kaynaklık insan kaynaklı çatışmalar ve insan doğaya müdahalesi ise ayrı bir yer tutmaktadır. Çünkü bu tür nüfus hareketlerine dâhil olan kişiler diğer göç türlerine göre daha fazla tehlikeyle karşı karşıya kalmakta (İnce, 2018), afet etkisi ortaya çıkabilmekte ve böyle bir sürecin birçok bağlamda afetle sonuçlanması kaçınılmaz olmaktadır. Sığınmacıların ikamet ettikleri kamp ortamlarının kötü koşullara sahip olması salgın hastalıkların sığınmacılar arasında başlamasına neden olmakta ve hızlı yayılımı kolaylaştırmakta, düzensiz göç teşebbüsünde bulunanlar donarak, denizlerde boğularak kitlesel olarak hayatlarını kaybedebilmektedir. Sığınmacıların yöneldikleri ülkelerde gerekli hazırlıklar yapılmadığı zamanlarda sığınmacıların acil ihtiyaçları karşılanamamakta, ülkenin alt yapısı önemli oranda olumsuz etkilenebilmektedir. Gümünüz dünyasında ortaya çıkan gelişmelere bağlı olarak afet ile göç arasındaki ilişki giderek güçlendiği görülmektedir.

\section{Afetlertin Yapısal Dönüşümü ve COVID-19}

Modern çağdaki afetlerin yapısında meydana gelen değişim ve dönüşümün bir takım izlerini günümüzde neredeyse bütün dünyayı etkisi altına alan COVID-19 salgın hastalığında bulmak mümkündür. Öncelikle kitlesel ölümlere neden olduğu, toplusal düzeni alaşağı, gündelik hayatı radikal bir biçimde değişime uğrattığı, önemli oranda mal kaybına neden olduğu, insanların kısa vadede çözüm geliştiremediği için COVID-19'un olumsuz etkilerini tarihteki diğer salgın hastalıklar gibi afet kapsamında değerlendirmenin mümkün olabileceği düşünülmektedir. Ancak modern çağda meydana gelen birçok afet örneğinde olduğu gibi COVID-19 da geleneksel dönemde zaman zaman baş gösteren salgın hastalıklardan bir takım farklı özellikler sergilemektedir. İnsanlık tarihinde birçok salgın hastalığa rastalanmakla birlikte (Nikiforuk, 2018) COVID-19 salgın hastalığını geleneksel dönemde görülen diğer salgın hastalıklardan ayıran temel karakteristik özelliklerden biri modern çağda afetlere neden olan diğer olaylar gibi tahrip gücünün oldukça yükssek olmasıdır. Bu kapsamda sağlık hizmetleri daha önce benzeri görülmemiş bir sağlık krizi ile karşı karşıyadır ve hastalık bulaşan hasta sayısı dünyada her geçen gün artış göstermektedir (Balasubramanian, 2020).

COVID-19, ortaya çıktığı Çin'in sadece Wuhan kentini değil neredeyse bütün dünyayı etkileyen ve küresel sistemi alaşağı eden bir karaktere bürünmüştür. Şüphesiz COVID-19 bu tahripkâr gücünü sadece fonksyonel boyutundan değil küreselleşme, yeni toplumsal örgütlenme 
biçimi, araçsal akıl, işbölümü, kentleşme, yeni teknoloji gibi modern hayatın unsurlarından almaktadır.

Özellikle son yirmi yılda küreselleşme, salgın hastalıkların yayılımını kolaylaştıması kapsamında sahip olduğu kapasite insanlar için bir tehdit oluşturmaktadır. Küreselleşme ile birlikte ülkelerarası insan hareketliliğinin artması COVID-19'un diğer ülkelere taşınmasında başat rol oynamıştır. COVID-19, modern küreselleşmenin sunduğu imkânlar sayesinde ortaya çıktığı Çin'nin Wuhan kentinden sınırlar ötesine taşınması şaşırtıcı bir biçimde sadece haftalar içersinde gerçekleşmiştir. Çin'in uluslararası ticarette önemli bir paya sahip olması ve dünyadaki neredeyse bütün ülkelerle alışveriş içinde olması salgının dünyanın diğer bölgelerine ihraç edilmesinde aktif rol oynamıștır. COVID-19'un dünyaya bu kadar hızlı yayılması ona daha önceki salgın hastalıklardan ayıran bir karakter kazandırmaktadır. Dünyada gelişen sağlık hizmetleriyle daha önceki salgın hastalıklara bir çözüm bulunsa da COVID-19'un bu kadar hızlı yayılması ve aş1 çalışmalarının zaman alması tahrip gücünü artıran bir unusur olmaktadır (Mas-Coma vd., 2020).

Modern çağla birlikte insanların büyük çoğunluğunun artık kentlerde ikamet etmesi, gündelik kent hayatında insanlar arası alışverişin fazla olması, fiziksel ve sosyal temasın kolay ve sık olması COVID-19'un hızlı yayılımını kolaylaştıran diğer önemli bir faktör olmuştur. Aşı çalışmaları olumlu sonuçlanıncaya kadar COVID-19 ile mücadelede salgını kontol etmenin temel staratejilerden biri insanların birbirlerinden fiziksel olarak uzak durup temas kurmamasıdır. Ancak kentlerdeki insanların sahip olduğu sosyal doku buna pek müsaade etmemektedir. Yayılma hızı açısından insanlık tarihinde önemli bir yere sahip olan COVID-19, bu karakterinin önemli bir kısmını kentleşmiş ve birbiriyle bağlantılı hale gelmiş toplumsal örgütlenme biçiminden aldığı söylenebilir. COVID-19, modern çağlala birlikte giderek daha da birbirine bağlı hale gelen insan toplumları için aynı zamanda eşi görülmemiş küresel bir sağlık ve ekonomik tehdit kaynağını da oluşturmaktadır (Stier vd., 2020). Bu kapsamda küreselleşme ve geleneksel dönemin aksine umanlaşma ile birlikte birbirine bağımlı hale gelen toplumlar ve bireyler salgın sürecini daha ağır bir biçimde deneyimlemesine neden olmuş ve salgın hastalık küresel bir boyuta dönüş̧erek küresel iş birliği ve mücadele ihtiyacını ortaya çıkaran bir hususiyet kazandırmıştır.

COVID-19'un tahrip gücünün fazla olmasının diğer bir nedeni de insanın bağışıklık sisteminin zayıf olmasıdır. Modern çağda yeni teknolojinin sağladığı imkân sayesinde gıdanın transferi, uzun süre muahafaza edilmesi ve verimin artırılması için üretim sürecine, yapısına müdahele edilmesi (Giddens, 2012: 298), başka bir ifade ile doğal yapsının değişime uğratılması salgın hastalıklarda etkin rol oynayan insanın bağışıklık sisteminin zayıflamasına neden olmaktadır (Nikiforuk, 2018).

COVID-19'u geleneksel dönemdeki salgın hastalıklardan ayıran diğer temel bir özelliği farklı toplumsal tabakanın bütün bireylerini tehdit etmekle birlikte daha çok yoksul, yaşlı, dezavantajlı sosyal grupları olumsuz etkilemesidir. Araşsal aklın liderliğinde ekonomik sermayeyi maksimize etme şiarıyla hereket eden neo-liberal ekonomik politikalar, toplumsal tabakalar arası farkı derinleştirerek bu kesimlerin salgın hastalıktan farklı şekillerde etkilenmesine neden olmuştur. Bazı ülkelerde COVID-19 hastalığından ölen insanların \%71'inin huzur evlerinde kalanların oluşturması sosyal grup, sınıfsal eşitsizlik ve afet arasındaki ilişkiyi gösteren güncel bir örnek oluşturmaktadır ${ }^{5}$. Yine eşitsizliklerin kurumsallaştığı ABD'de COVID-19 ile ilgili ulaşılan bilgiler toplumsal konum ile afete maruz kalma arasındaki ilişki net bir biçimde göstermektedir. Elde edilen verilere göre Michigan eyaletinde siyahi nüfus toplam nüfüsun \%15'ini oluş̧urmasına rağmen COVID-19'a yakalananların \%35'ini oluşturması ve yine siyahilerin tüm ölen kişilerin \%40'ını oluşturması; Illinois'da siyahiler eyalet nüfusunun yaklașı \%16'1sını olușturmasına rağmen COVID-19 teşhisi konulan insanların \%30'unu temsil etmesi; Şigago'da siyahilerin koronavirüsten ölen insanların \%70'ini oluşturmas1; diğer ayaletlerde de benzer bir duruma rastlanması, bazı

\footnotetext{
${ }^{5}$ http://m.haber7.com/guncel/haber/2975792-kayiplarin-yuzde-yetmisi-huzurevinde, Erişim tarihi: 18.05.202
} 
ilçelerde hastanenin bile olmaması 1rksal, etnik ve toplumsal konumun COVID-19 sürecinde nasıl eşitsizliklere yol açtığını açıkça göstermektedir. ${ }^{6}$

COVID-19'un geleneksel dönemdeki salgın hastalıklardan ayırıcı diğer bir özelliği de afet ve siyaset arasıdaki ilişkiyi güçlü bir biçimde yansıtmasıdır. Modern çağda afetlerin kaynağı olarak ilahi ceza yerine insanın teknik davranışları ve politik kararların görülmesi, insanın suçlu bulunması açısından COVID-19'a yüklenilen anlam, uzman önerilerinin toplumsal hayatın kurgulanması üzerinde oldukça etkili olması afet ve siyaset arasındaki ilişkiyi göstermesi bağlamında önemli oduğu düşünülmektedir. COVID-19 sonrası ölümlerin fazla olduğu bazı ülkelerde siyasi liderler uzmanların önerileri dikkate almadığı varsayılarak halk tarafından bu liderlere yönelik kalabalık protestoların düzenlenmesi bu kapsamda değerlendirilebilir. COVID-19 ile ilgili bütün bilgi kaynakları ve uzmanların uyarılarına rağmen özellikle gelişmiş Avrupa ülkeleri politikacılarının önlem almada geç eyleme geçmesi şaşkınlıkla karşılanmaktadır (Mas-Coma vd., 2020). Bu durum afetler ile siyaset arasındaki ilişkinin güçlenemeye başladığına işaret etmektedir. Diğer taraftan siyaset afetlerin ortaya çıkışını engellemede ve kontrol altına alınmasında da önemli bir rol üstlenmektedir. Siyaset afetlere karşı ciddi bir hazırlık yaptığında ve afetlere karşı başarılı bir politika sergilediğinde ükeyi yöneten hükümetler halkın teveccühünü kazanabilmekte ve siyasal konumları pekişebilmektedir.

\section{Sonuç}

Modernleşme ile birlikte toplumsal hayatın birçok alanında radikal değişimler meydana geldiği gibi toplumsal yapının daimî bir parçasını oluşturan afetlerin yapısında da bir dönüşüm olduğu görülmektedir. Afetle ilgili çalışmalar incelendiğinde afetlerin çoklu bir yapıya sahip olmaya başladığına rastlanılmaktadır. Süreç içerisinde afet kavramına yüklenilen anlam değişmekte afet sayısında özellikle insan kaynaklı afetlerde büyük bir artış olduğu ve yeni afet türlerinin ortaya çıktığ 1 anlaşılmaktadır (Furedi, 2007). Çin'in Wuhan kentinde ortaya çıkıp nereseyse bütün dünyaya yayılan COVID-19 gibi modern çağda lokal düzeyde ortaya çıkan afetler küresel bir boyut kazanmaktadır. Yine ileri teknolojinin toplumsal hayatta etkin bir biçime kullanılması, bir taraftan afetleri kısmi olarak kontrol altına alma imkânı sağlasa da birçok riski beraberinde getirerek potansiyel tehlikelerin afete dönüşmesine olanak tanımaktadır. Bununla birlikte kentleşme ve yeni toplumsal örgütlemenin diğer parametreleri yeni tehlike alanları açmaktadır. İnsan kaynaklı bu tehlike, risk artışı ve bunların bir kısmının afete dönüşmesi daha travmatik sonuçlar doğurmaktadır (Weisæth vd., 2002). Afetlerin artışı zorunlu kitlesel göçlerin artışına yol açarken göçün kendisi de zaman zaman bir afete sebebiyet verebilmektedir (Varol \& Gültekin, 2016). Afetler COVID-19 örneğinde olduğu gibi bütün toplumları ve bireyleri tehdit eden bir olgu olsa da (Balasubramanian, 2020) toplumların ve bireylerin sahip olduğu ekonomik kalkınma düzeyi ve diğer sermaye biçimleri onların bu süreçten farklı şekillerde etkilenmesine neden olmaktadır (Bolin, 2007).

Yakın dönemde afetlerin yapısında meydana gelen değişim ve dönüşümün karakteristik birtakım özelliklerine COVID-19'da da rastlamak mümkündür. Küreselleşme, kentleşme ve insanların daha fazla birbiriyle bağlantılı hale gelmesi bir salgın hastalık olarak COVID-19'un tarihte benzeri görülmemiş bir biçimde hızlı yayılımını sağlamıştır. Modern çağdaki afet örneklerinde yaygın bir biçimde görüldüğü gibi COVID-19 bütün toplumsal tabakaları tehdit etmesine rağmen çeşitli sermaye biçimlerinden yoksun olan insanları daha fazla olumsuz etkilemiştir. Yine insanın doğayı daha fazla tahrip etmesi COVID-19'un küresel bir soruna dönüşmesinde etkili olmuştur (Mas-Coma vd., 2020).

Modern çağda özellikle insan kaynaklı tehlikelerin artışı ve bunların önemli bir kısmının afetle sonuçlanması şöyle bir soruyu beraberinde getirmektedir. Tehlikeleri kontrol atına almak ve dolayısıyla afetleri tamamen engellemek mümkün müdür? İnsanlık tarihi boyunca afetlerin

\footnotetext{
${ }^{6}$ https://www.brookings.edu/blog/fixgov/2020/04/09/why-are-blacks-dying-at-higher-rates-from-covid-19/, Erişim tarihi: 15.06.2020
}

Turkish Studies, 15(4) 
toplumsal yapının bir parçasını oluşturması hem doğa kaynaklı hem de insan kaynaklı afetlerin tamamen ortadan kaldırılmayacağına güçlü bir işarettir. Bununla birlikte Nikiforuk (2018) ve COVID-19'dan hareketle Balasubramanian (2020) afetlerin etkisini azaltmak adına insanoğluna doğayla savaşmak yerine barış yapmayı önermektedir. Diğer taraftan afetlerin insanlık tarihi boyunca var olması bireylerin ve toplumların afetlere karşı bir hazırlık yapmaması gerektiği anlamına gelmemektedir. Belli bir toplumun, hatta toplumların çıkarı, toplumsal fayda belli bir kesimin, belli bir toplumun ve devletin çıkarına feda edilmedikçe; toplum sözleşmesinde olduğu gibi bireyler, toplumlar, devletler hayatlarını birtakım tehlikelerden korumak için konforundan ve bazı çıkarlardan ödün verdiğinde afetleri ve afetlerin olumsuz etkilerini sınırlandırmanın mümkün olabileceği düşünülmektedir.

\section{Kaynakça}

Akgüngör, A. Ç. (2010). Toplumbilim perspektifinden afeti düşünmek. LAÜ Sosyal Bilimler Dergisi, 1(1), 3-22.

Alexander, D. (2005). "An interpretation of disaster in terms of changes in culture, society and international relations." What Is a Disaster? New Answers to Old Questions (Eds.) Ronald W. Perry \& E.L. Quarantelli. Xlibris Corporation. 25-38.

Balasubramanian, M. (2020). Covid 19-The new age pandemic. Notion Press.

Beck, U. (2011). Risk toplumu: Başka bir modernliğe doğru. (Çev.) K. Özdoğan ve B. Doğan. İthaki Yayınları.

Boin, A. \& 't Hart, P. (2007). “The Crisis approach.” Handbook of Disaster Research (Eds.) Havidán Rodríguez. Enrico L. Quarantelli \& Russell. R. Dynes. Springer Science+Business Media, LLC. ss. $42-54$.

Bolin, B. (2007). "Race, class, ethnicity, and disaster vulnerability." Handbook of Disaster Research (Eds.) Havidán Rodríguez, Enrico L. Quarantelli \& Russell. R. Dynes. Springer Science+Business Media, LLC. 113-129.

Durkheim, E. (2006). Toplumsal işbölümü. (Çev.) Ö. Ozankaya. Cem Yayınevi.

Fink, G. (2010). "Introduction." Stress of War, Conflict and Disaster (Ed.) George Fink. Academic Press is an imprint of Elsevier.

Furedi, F. (2007). The changing meaning of disaster. Area, 39(4), 482-489.

Giddens, A. (2012). Sosyoloji. (Haz.) C. Güzel. Kırmızı Yayınları.

Gluchman, V. (2016). Moral theory and natural, or social, Disasters (Editorial). Human Affairs, (26), 3-7.

İnce, C. (2018). Uluslararası göç bağlamında Türkiye'deki Suriyeli göçmenlerin mekânsal yoğunlaşması. IKSAD Publishing House.

İnce, C. (2019). "Sosyal afetler: Savaş, iç çatışma ve bir mücadele biçimi olarak göç". 3. Uluslararası Sosyal ve Beşeri Bilimler Kongresi, 20-22 Aralık 2019, Van, Türkiye.

Lin, L., Nilsson, A., Sjölin, J., Abrahamsson ve Tehler, H. (2015), On the perceived usefulness of risk descriptions for decision-making in disaster risk management. Reliability Engineering and System Safety, 142, 48-55.

Mas-Coma, S., Jones, M. K., \& Marty, A. M. (2020). COVID-19 and globalization. One Health, 9, 1-4.

Münkler, H. (2010). Yeni savaşlar. (Çev.) Z. A. Yılmazer. İletişim Yayınları. 
Nikiforuk, A. (2018). Mahşerin dördüncü atlısı: Salgın ve bulaşıcı hastalıklar tarihi. (7. Baskı, Çev.) S. Erkanlı. İletişim Yayınları.

OECD. (2003). Emerging Risks in the 21st Century: An agenda for action. Paris, https://www.oecd.org/futures/globalprospects/37944611.pdf

Okumuş, E. (2002). Tabii afetler, din ve toplum: Marmara depremi örneği. İslami Araştırmalar Dergisi, 15(3), 339-373.

Özer, Y. E. (2017). Afet konusundaki algı ve yerel aktörlerin sorumlulukları. Sayıştay Dergisi, 106, $1-34$.

Perrow, C. (2007). "Disasters Ever More? Reducing U.S. Vulnerabilities." Handbook of Disaster Research (Eds.) Havidán Rodríguez, Enrico L. Quarantelli \& Russell. R. Dynes. Springer Science+Business Media, LLC. 521-533.

Perry, R. \& Quarantelli, E. (2005). "Introduction". What Is a Disaster? New Answers to Old Questions (Eds.) Ronald W. Perry \& Enrico L. Quarantelli. Xlibris Corporation. 325-396.

Perry, R. W. (2007). "What 1s a disaster?". Handbook of Disaster Research (Eds.) Havidán Rodríguez, Enrico L. Quarantelli \& Russell. R. Dynes. Springer Science+Business Media, LLC. 1-15.

Quarantelli, E.L., Lagadec, P. \& Boin, A. (2007). "A heuristic approach to future disasters and crises: New, old, and in-between types.” Handbook of Disaster Research (Eds.) Havidán Rodríguez, Enrico L. Quarantelli \& Russell. R. Dynes. Springer Science+Business Media, LLC. 16-41.

Rodr'iguez, H., Diaz, W., Santos, J.M., \& Aguirre, B. E. (2007). "Communicating risk and uncertainty: science, technology, and disasters at the crossroads." Handbook of Disaster Research (Eds.) Havidán Rodríguez, Enrico L. Quarantelli \& Russell. R. Dynes. New York: Springer Science+Business Media, LLC. 476-488.

Stier, A., Berman, M., \& Bettencourt, L. (2020). COVID-19 attack rate increases with city size. Mansueto Institute for Urban Innovation Research Paper No. 19, https://ssrn.com/abstract=3564464

Taylor, C. (2011). Modernliğin sıkıntıları. (2. Baskı, Çev.) U. Canbilen. Ayrıntı Yayınları.

Teodorescu, H. N. (2015). Using analytics and social media for monitoring and mitigation of social disasters. Procedia Engineering, 107, 325-334.

Tunç, A. Ş. (2018). “Afete dönüşen kitlesel göçler”. Göç ve Göçmen Sorunları (Ed.) Verda Canbey Özgüler. Anadolu Üniversitesi Yayınları. 65-68.

Turner, B. S. (2002). Oryantalizm, postmodernizm ve globalizm. (Çev.) İ. Kapaklıkaya. Anka Yayınlar1.

Varol, N. \& Gültekin, T. (2016). Etkin bir göç faktörü: afetler. Antropoloji, (32), 43-51.

Waugh, W. L. (2007). "Terrorism as Disaster." Handbook of Disaster Research (Eds.) Havidán Rodríguez, Enrico L. Quarantelli \& Russell. R. Dynes. Springer Science+Business Media, LLC. 388-404.

Weisæth, L., Knudsen Jr, Ø., \& Tønnessen, A. (2002). Technological disasters, crisis management and leadership stress. Journal of Hazardous Materials, 93(1), 33-45. 